\title{
Assessing the photodynamic therapeutic effects of 5-aminolevulinic acid on human colon cancer cells using light-emitting diodes
}

\author{
EMAAN TANVIR SHAH, HAGER ALI OMAR MESRATI, USAMA JEHAD ALDALLAL, \\ FATEMA ABDULWAHAB, FRYAD ZEKI HENARI and STEPHEN TIMOTHY SAFRANY
}

Department of Medicine, RCSI Bahrain, P.O. Box 15503, Adliya, Bahrain

Received September 16, 2020; Accepted July 5, 2021

DOI: 10.3892/wasj.2021.114

\begin{abstract}
The minimal invasiveness and high selectivity of 5-aminolevulinic acid (5-ALA)-based photodynamic therapy (PDT; 5-ALA-PDT) renders it a viable therapeutic option for the treatment of various types of cancer. Compared with conventional lasers, light-emitting diodes (LEDs) are an inexpensive and convenient low-energy light source option. Nevertheless, the scope of LEDs in the 5-ALA-PDT of colorectal cancer (CRC) has yet to be fully determined. Thus, the aim of the present study was to assess the efficacy of LEDs in the 5-ALA-PDT of colon cancer in vitro by evaluating cytotoxic activity. 5-ALA-treated human CRC cells (SW480) were irradiated with LEDs of varying wavelengths: Red $(630 \mathrm{~nm})$, green $(515 \mathrm{~nm})$, blue $(456 \mathrm{~nm})$ and violet $(399 \mathrm{~nm})$. An MTS assay was conducted to determine cell viability. Additionally, a concentration-response experiment was conducted with the most therapeutic wavelength (violet) to examine the 5-ALA pharmacodynamics in vitro. The results revealed that only violet light in 5-ALA-PDT produced antitumour activity; this combination alone produced a drug concentration- and energy-related decrease in cell viability. The decrease in viability was partially reversed by 3-methyladenine, but not by Z-VAD(OMe)-FMK, suggesting that 5-ALA induced the autophagy, but not the apoptosis of SW480 cells. The nature of the multi-well plates used markedly affected the effectiveness of PDT. Black-walled plates appeared to protect approximately
\end{abstract}

Correspondence to: Professor Stephen Timothy Safrany, Department of Medicine, RCSI Bahrain, P.O. Box 15503, Adliya, Bahrain

E-mail: ssafrany@rcsi-mub.com

Abbreviations: 5-ALA, 5-aminolevulinic acid; CRC, colorectal cancer; DMSO, dimethyl sulfoxide; LED, light-emitting diode; PBS, phosphate-buffered saline; PDT, photodynamic therapy; PpIX, protoporphyrin IX

Key words: 5-aminolevulinic acid, 96-well plates, cell proliferation, colorectal cancer, photodynamic therapy
$25 \%$ of cells from the effects of PDT. By contrast, clear plates permitted light access to the wells, even when protected from direct PDT treatment. On the whole, the findings of the present study indicate that the use of LEDs in 5-ALA-PDT in vitro induce the fluence-dependent tumour cell death of SW480 cells. The choice of multi-well plates greatly affects the results obtained in vitro. The antitumour effect was high with violet light. Hence, the use of LEDs in 5-ALA-PDT may prove to be an effective potential treatment for CRC.

\section{Introduction}

Currently, colorectal cancer (CRC) is considered to be the third most frequent type of cancer and the second most frequent cause of cancer-related mortality worldwide (1). While treatments and recovery rates continue to improve $(2,3)$, there is current evidence to indicate a new wave of early-onset CRC, described as being diagnosed in patients $<50$ years of age (4). The primary treatment modality in CRC is surgical resection, frequently accompanied by chemotherapy as an adjuvant (5). Recurrence is a common issue, with an estimated $30-50 \%$ of patients suffering from recurrence within the first 5 years following surgery (3). Unresectable stage II or III tumours could possibly decrease in size with radiation therapy, making them eligible for surgical resection. Regrettably, however, radiation therapy has several side-effects (6). Furthermore, there is a trend in that the efficacy of current CRC therapies is decreasing due to the development of resistance, which has been found to occur in almost all patients with CRC (7). Hence, the necessity for novel CRC treatment modalities is undeniable.

A promising treatment modality used in controlling several types of cancers is photodynamic therapy (PDT) $(8,9)$. Depending upon the location of the targeted tissue, it involves the topical or intravenous delivery of a photosensitiser: A molecule that accumulates in target cells (and/or tissue). The light of a specific wavelength can activate the photosensitiser. The absorbance of photons excites the photosensitiser to a higher energy state, causing it to react with molecular oxygen and produce free reactive oxygen species that induce cell death (10). The major advantage of PDT, in contrast to conventional radio- and chemotherapy, is its selectivity in cell 
destruction, which minimises the harm inflicted to adjacent healthy tissue $(11,12)$.

Protoporphyrin IX (PpIX) is a safe, innate photosensitiser produced in the mitochondria from 5-aminolevulinic acid (5-ALA) (11-13). It has been demonstrated that following treatment with 5-ALA, PpIX accumulates in malignant cells, rendering it a good candidate for photodynamic therapy (13). Despite its long history, the use of 5-ALA-based PDT (5-ALA-PDT) in vitro is proving to be problematic. The high cost and energy output of lasers cause limitations to their use. While such lasers are used to treat skin, thermal damage can occur (14).

The present study addresses a few points from the literature regarding 5-ALA-PDT and identifies novel concerns and issues regarding its use. The main aim of the present study was to assess the efficacy of light-emitting diodes (LEDs) as a light source in the 5-ALA-PDT treatment of the SW480 colorectal cancer cell line.

\section{Materials and methods}

Cells and cell culture. The SW480 human colorectal cell line (a kind gift from Dr G.B. Willars, University of Leicester, UK) was grown in high-glucose DMEM (D5796, Sigma-Aldrich; Merck KGaA) enhanced with $10 \%$ foetal calf serum (F7524, Sigma-Aldrich; Merck KGaA), $100 \mu \mathrm{g} / \mathrm{ml}$ streptomycin and $100 \mathrm{U} / \mathrm{ml}$ penicillin (F4333, Sigma-Aldrich; Merck KGaA). Mycoplasma testing was performed prior to the use of these cells in the experiments described below.

Cells were grown and tested using two different types of 96-well multi-plates: Black-walled cell plates (3603, Costar; Corning, Inc.); or clear plates (655180, Greiner; Sigma-Aldrich; Merck KGaA). Each plate was seeded with SW480 cells (20,000 cells/well) or medium alone. Phosphate-buffered saline (PBS; pH 7.4) was seeded in between wells to limit the edge effect (15). Cells were incubated in a humidified incubator containing $5 \% \mathrm{CO}_{2} / 95 \%$ air at $37^{\circ} \mathrm{C}$ for $24 \mathrm{~h}$.

Preparation of 5-ALA. 5-ALA (A3785, Sigma-Aldrich; Merck KGaA) was dissolved in dimethyl sulfoxide (DMSO) (100 mM). Each $100 \mu \mathrm{l}$ was diluted in $880 \mu \mathrm{l} \mathrm{PBS}$ and $\mathrm{pH}$ adjusted to 7.4 by the addition of $20 \mu \mathrm{l}$ of $1.5 \mathrm{M}$ Tris ( $\mathrm{pH} 8.8$ ), yielding a $10-\mathrm{mM}$ solution of 5-ALA. Further dilutions were performed in PBS.

Photodynamic therapy light sources. Cultured cell plates were exposed to four different LED lights: $\operatorname{Red}\left(630 \mathrm{~nm}, 2.1 \mathrm{~mW} / \mathrm{cm}^{2}\right)$, green $\left(515 \mathrm{~nm}, 1 \mathrm{~mW} / \mathrm{cm}^{2}\right)$ and blue $\left(456 \mathrm{~nm}, 1 \mathrm{~mW} / \mathrm{cm}^{2}\right)$ using a $30 \mathrm{~W}$ U'King multi-LED stage lamp purchased from Shenzhenshi Yimosi, as well as violet $\left(399 \mathrm{~nm}, 3 \mathrm{~mW} / \mathrm{cm}^{2}\right)$ using a MICTUNING 18x3 W LED stage lamp purchased from amazon.co.uk. Light intensity was determined using a pyroelectric photo-radiometer. The time required for exposure was calculated using $1 \mathrm{~mW} / \mathrm{cm}^{2} \mathrm{x}$ seconds exposure $=\mathrm{mJ} / \mathrm{cm}^{2}$.

Photodynamic activation. Following $24 \mathrm{~h}$ of culture, the medium was supplemented with $10 \mu \mathrm{l}$ of $10 \%$ DMSO in PBS (vehicle) or 5-ALA (1.25 mM-10 mM; final concentration, $125 \mu \mathrm{M}-1 \mathrm{mM})$. Following a set time, the medium containing 5-ALA or PBS was removed and replaced with fresh PBS. The cell plates were placed on a heating block set at $37^{\circ} \mathrm{C}$ and irradiated with a $0-4 \mathrm{~J} / \mathrm{cm}^{2}$ light of the set wavelength. In a previous study, a single plate was used for several time points of light irradiation. Wells were protected from irradiation by covering them with aluminium foil (16).

Determination of the mechanisms of cell death. The mechanisms through which 5-ALA induces cell death were investigated using $30 \mu \mathrm{M}$ Z-VAD(OMe)-FMK (ab120487, Abcam, prepared as a $10-\mathrm{mM}$ stock solution in DMSO and diluted in PBS) or 3 mM 3-methyladenine (ab120841, Abcam, prepared as a $30 \mathrm{mM}$ working solution in PBS). Each reagent was added immediately prior to the addition of $250 \mu \mathrm{M} 5$-ALA. Each reagent was also present during the light irradiation step and the subsequent 48 -h post-irradiation incubation period.

Assessment of cell viability by MTS assay. At $48 \mathrm{~h}$ post-irradiation, cell viability was assessed by MTS assay, as previously described (17). The absorbance $(490 \mathrm{~nm})$ of the samples was determined immediately and $2 \mathrm{~h}$ after the addition of the reagent (10 $\mu \mathrm{l}$ MTS reagent; $2 \mathrm{mg} / \mathrm{ml}$ MTS containing $0.04 \mathrm{mg} / \mathrm{ml}$ PMS). The absorbance at time zero was subtracted from the absorbance following $2 \mathrm{~h}$ of incubation in a humidified incubator at $37^{\circ} \mathrm{C}$ to obtain the signal reading. To determine changes in viability, pairwise comparisons were made between cells receiving 5-ALA and those receiving 10\% DMSO in PBS for each light exposure time point. This was done to remove any bias from light-induced cell damage at each wavelength (18). Each experiment was repeated at least four times in triplicate.

Curve fitting. Curve fitting, where appropriate, was performed using GraphPad Prism software (v.9.0.2; GraphPad Software, Inc.). The results are presented as the mean values and standard error of the mean.

Statistical analysis. Paired data were analysed and compared using one-way ANOVA and Dunnett's post hoc test or a Bonferroni post hoc test to correct for multiple analyses using GraphPad Prism (v.9.0.2; GraphPad Software, Inc.).

\section{Results}

Efficacy of LED in the 5-ALA-PDT ofCRC in vitro.Initially, the MTS assay was used to assess the efficacy of 5-ALA-mediated PDT on SW480 cells grown in black-walled, clear bottomed 96-well plates. The cells were treated with 5-ALA $(1 \mathrm{mM})$ for $4 \mathrm{~h}$ before the medium was removed and replaced with PBS. The cells were then exposed to light of different wavelengths (red, $630 \mathrm{~nm}$; green, $515 \mathrm{~nm}$; blue, $456 \mathrm{~nm}$; and violet, $399 \mathrm{~nm}$ ) for increasing amounts of time (and hence, increasing fluence at these set wavelengths). In addition, some wells were treated with 5-ALA and not exposed to light.

The combination of 5-ALA $(1 \mathrm{mM})$ with red $\left(3.78 \mathrm{~J} / \mathrm{cm}^{2}\right)$, green $\left(3.60 \mathrm{~J} / \mathrm{cm}^{2}\right)$, or blue $\left(3.60 \mathrm{~J} / \mathrm{cm}^{2}\right)$ light did not significantly affect the viability of the SW480 cells when compared with the 'no light' control ( $\mathrm{P}>0.35$, one-way ANOVA, multiple paired comparisons, Dunnett's post hoc analysis) (Fig. 1). By contrast, the 5-ALA (1 mM)-treated cells exposed to violet light exhibited a rapid loss of viability. A fluence of $0.18 \mathrm{~J} / \mathrm{cm}^{2}$ was sufficient to significantly decrease cell viability $(\mathrm{P}=0.014)$. Higher fluences caused a greater reduction in cell viability $(\mathrm{P}<0.005$ in all cases). 


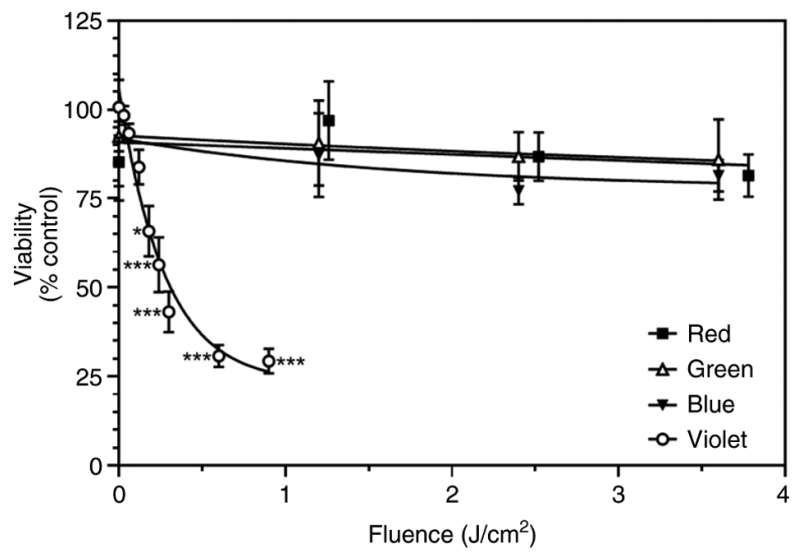

Figure 1. SW480 cell viability was measured by MTS assay with the increasing light fluence $\left(\mathrm{J} / \mathrm{cm}^{2}\right)$ of different wavelengths: Red $(630 \mathrm{~nm})$, green $(515 \mathrm{~nm})$, blue $(456 \mathrm{~nm})$ and violet $(399 \mathrm{~nm})$ following treatment with $1 \mathrm{mM}$ 5 -ALA for $4 \mathrm{~h}$. Data are presented as the mean \pm SEM of four (red, green, blue) or nine (violet) independent experiments. 5-ALA, 5-aminolevulinic acid. ${ }^{*} \mathrm{P}=0.014$ and ${ }^{* * *} \mathrm{P}<0.005$ when compared with the zero-hour control.

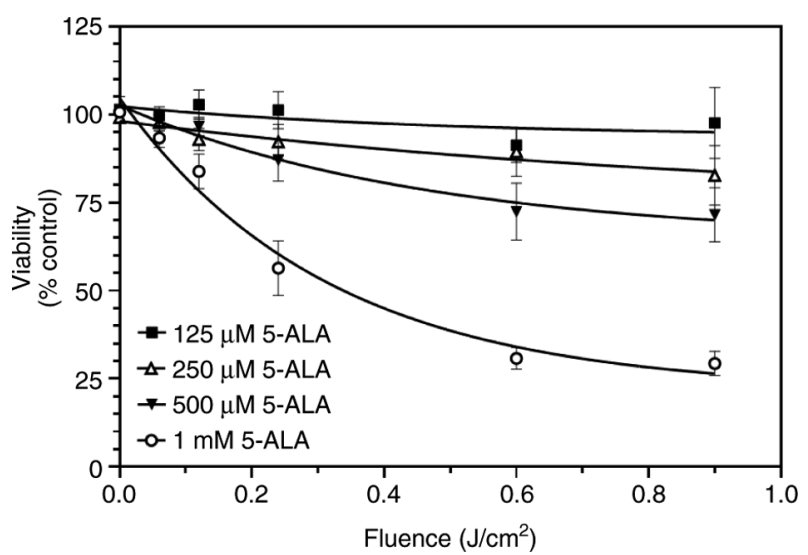

Figure 2. SW480 cells were incubated with increasing concentrations of 5-ALA (125 $\mu \mathrm{M}-1 \mathrm{mM})$ and then exposed to violet light $\left(0.06-0.9 \mathrm{~J} / \mathrm{cm}^{2}\right)$. Data are presented as the mean \pm SEM from six $(125-500 \mu \mathrm{M})$ and nine $(1 \mathrm{mM})$ independent experiments. 5-ALA, 5-aminolevulinic acid.

The maximum decrease in cell viability appeared to plateau at approximately $75 \%$ (Fig. 1). The fluence required to reduce cell viability to $50 \%$ was $0.31 \mathrm{~J} / \mathrm{cm}^{2}$ in the presence of $1 \mathrm{mM} 5$-ALA.

5-ALA concentration-response curve. The concentration-dependent effects of 5-ALA on SW480 cell viability were then assessed. This was determined using 5-ALA $(125 \mu \mathrm{M}-1 \mathrm{mM})$ and fluences of violet light $\left(0.06-0.9 \mathrm{~J} / \mathrm{cm}^{2}\right)$. The loss of viability was concentration-dependent: Treatment with $1 \mathrm{mM}$ 5-ALA led to a greater decrease in viability at all time points, whereas $125 \mu \mathrm{M}$ appeared to have a minimal effect, if any (Fig. 2). Fitting these curves to a single exponential decay revealed plateau values of 94,64, 44 and $22 \%$ of time 0 control for 125, 250,500 $\mu \mathrm{M}$ and $1 \mathrm{mM}$ 5-ALA, respectively (Fig. 2). The fluence required to reduce cell viability to $50 \%$ was $0.34 \mathrm{~J} / \mathrm{cm}^{2}$ in the presence of $1 \mathrm{mM} 5$-ALA.

5-ALA treatment time-course. The time required for 5-ALA to exert its optimal effects on SW480 cell viability was then assessed. This was determined using 5-ALA (125 $\mu \mathrm{M}-1 \mathrm{mM})$

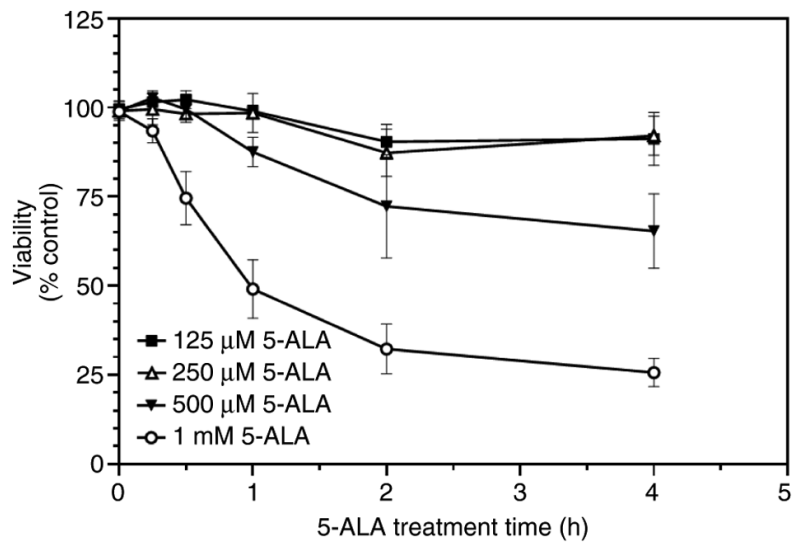

Figure 3. SW480 cells were incubated with increasing concentrations of 5-ALA $(125 \mu \mathrm{M}-1 \mathrm{mM})$ for $15 \mathrm{~min}$ to $4 \mathrm{~h}$ and then exposed to violet light $\left(0.9 \mathrm{~J} / \mathrm{cm}^{2}\right)$. Data are presented as the mean \pm SEM from six $(125-500 \mu \mathrm{M})$ and $10(1 \mathrm{mM})$ independent experiments. 5-ALA, 5-aminolevulinic acid.

and a single fluence of violet light $\left(0.9 \mathrm{~J} / \mathrm{cm}^{2}\right)$; the 5-ALA treatment times ranged from $15 \mathrm{~min}$ to $4 \mathrm{~h}$. The loss of viability was time-dependent: Treatment with $1 \mathrm{mM} 5$-ALA led to a greater decrease at all time points, whereas 125 and $250 \mu \mathrm{M}$ appeared to have a minimal effect, if any (Fig. 3). There appeared to be a delay in 5-ALA exerting an effect (Fig. 3).

It was noted that the loss of viability reached a maximum of $\sim 75 \%$ in each analysis. Thus, it was considered whether the black walls of the 96-well plates were reducing the effective fluence to a proportion of the cell population. This may occur if the well sides were casting a shadow on some cells close to the edges of each well. These experiments were repeated using clear plates.

Initially, individual wells not intended to be irradiated were covered with aluminium foil to achieve time-course data. After a fixed time, the foil was moved to expose further wells to obtain the time-course. Three observations were made: Firstly, the viability of cells was reduced by $100 \%$ (in the presence of $500 \mu \mathrm{M}$ or $1 \mathrm{mM} 5$-ALA), indicating that all cells were exposed to violet light; secondly, the decline in viability required much less time than with black-walled plates; thirdly, wells covered with foil throughout exposure (0 time) exhibited a marked, concentration-dependent decrease in viability compared with their paired untreated controls (Fig. 4). This identified that light was reflecting/refracting and exposing all cells to light from above.

Therefore, these experiments were repeated using individual clear plates for each time point. Using separate plates, it was found that 5-ALA alone, or light alone, did not affect the growth of SW480 cells. In addition, two further observations were made: Under these conditions, viability was maximally decreased by $100 \%$; the fluence required to reduce cell viability to $50 \%$ was $0.08 \mathrm{~J} / \mathrm{cm}^{2}$ in the presence of $1 \mathrm{mM}$ 5-ALA (Fig. 5). These observations were in marked contrast to those obtained using black-walled plates (Fig. 2). Firstly, the combination of light plus 5-ALA was able to reduce viability by $100 \%$. Secondly, this reduction was more rapid than that observed in experiments using black-walled plates (Fig. 2). In the presence of $1 \mathrm{mM} 5$-ALA, the fluence required to reduce cell viability to $50 \%$ was $0.08 \mathrm{~J} / \mathrm{cm}^{2}$, in contrast to $0.34 \mathrm{~J} / \mathrm{cm}^{2}$ when using the black-walled plates. 


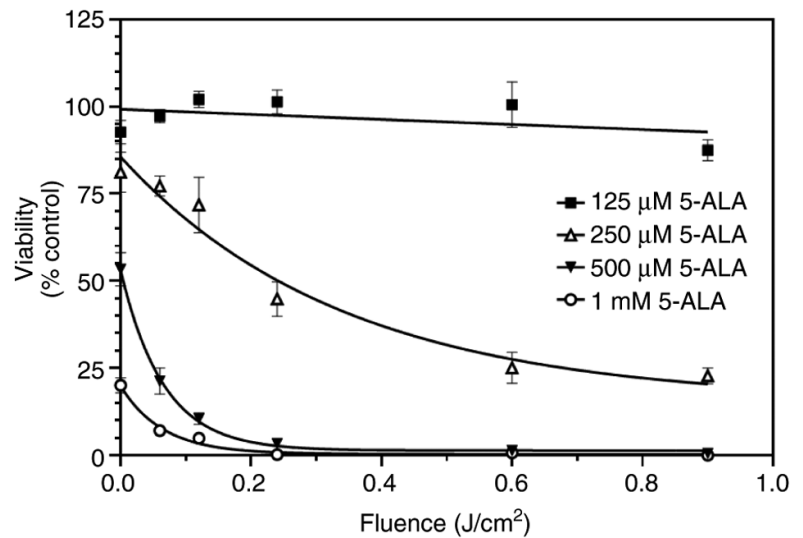

Figure 4. SW480 cells were grown in clear plates and incubated with increasing concentrations of 5-ALA $(125 \mu \mathrm{M}-1 \mathrm{mM})$ for $4 \mathrm{~h}$ and then exposed to violet light $\left(0.06-0.9 \mathrm{~J} / \mathrm{cm}^{2}\right)$. Foil was used to prevent light exposure to the wells until needed. Data are presented as the mean \pm SEM from four independent experiments. 5-ALA, 5-aminolevulinic acid.

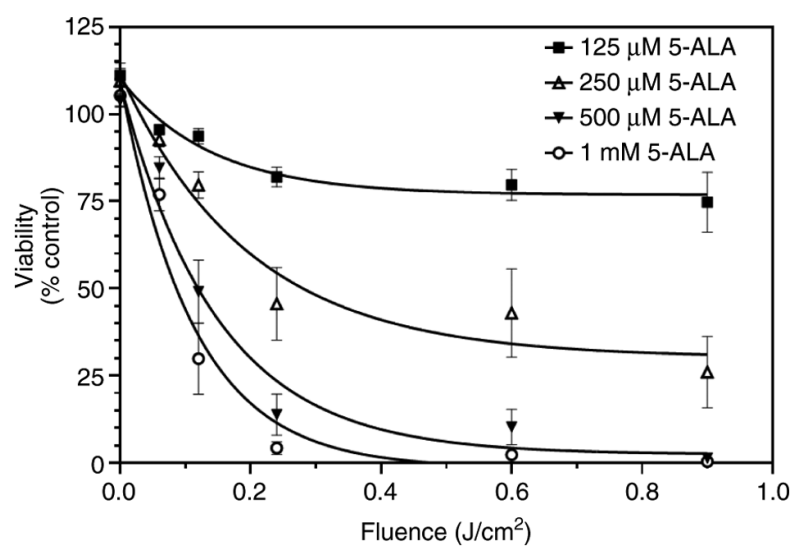

Figure 5. SW480 cells were grown in clear plates and incubated with increasing concentrations of 5-ALA $(125 \mu \mathrm{M}-1 \mathrm{mM})$ for $4 \mathrm{~h}$ and then exposed to violet light $\left(0.06-0.9 \mathrm{~J} / \mathrm{cm}^{2}\right)$. Individual plates were used for each time point, and wells were not covered with foil at any time. Data are presented as the mean \pm SEM from eight independent experiments. 5-ALA, 5-aminolevulinic acid.

Mechanism of action of 5-ALA. Finally, the present study sought to determine the death mechanisms of the SW480 cells. The addition of Z-VAD(OMe)-FMK $(30 \mu \mathrm{M})$ did not attenuate the effects of 5-ALA ( $>0.999$, one-way ANOVA, multiple comparisons, Bonferroni post hoc analysis), whereas 3-methyladenine $(3 \mathrm{mM})$ partially reversed these effects $(\mathrm{P}=0.0074)$ (Fig. 6). Neither reagent significantly affected the control values $(\mathrm{P}>0.999)$. This suggested that 5-ALA induced cell death via autophagy and not apoptosis.

\section{Discussion}

Generally, lasers are the prevailing light sources utilised in 5-ALA-PDT. However, over the years, several studies have reported the efficacy of LEDs in 5-ALA-PDT $(8,9)$. The present study demonstrated the efficacy of LEDs as a potential source of light in the 5-ALA-PDT of human CRC cells in vitro. Compared to lasers, LEDs are easy to use, cost-effective and convenient. The low wattage also results in a low-temperature

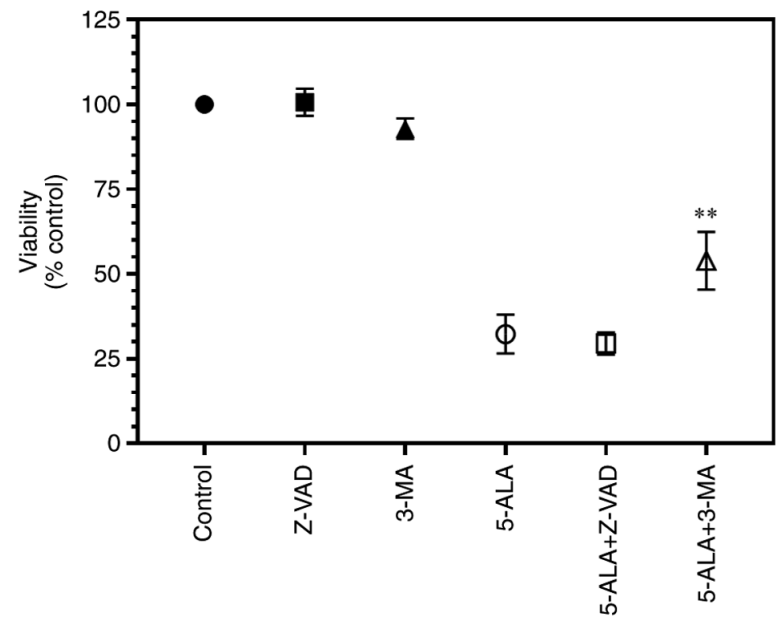

Figure 6. SW480 cells were grown in clear plates and incubated with 5-ALA $(250 \mu \mathrm{M})$ for $4 \mathrm{~h}$ in the presence of Z-VAD $(30 \mu \mathrm{M})$ or 3-MA $(3 \mathrm{mM})$ and then exposed to violet light $\left(0.9 \mathrm{~J} / \mathrm{cm}^{2}\right)$. Data are presented as the mean \pm SEM from eight independent experiments. ${ }^{* *} \mathrm{P}=0.0074$ when compared with the cells treated with 5-ALA alone. 5-ALA, 5-aminolevulinic acid; Z-VAD, Z-VAD(OMe)-FMK; 3-MA, 3-methyladenine.

device. The present study additionally preferred the use of LEDs as a light source in as they are safer than lasers, and do not require a sophisticated experiment set up $(8,9)$, which opens up the clinical possibility of using 5-ALA-PDT in third world countries that lack the resources for laser set ups. Additionally, LEDs possess the ability to irradiate a large area, which is another advantage over lasers. LEDs can be arranged in into a planner array to increase the irradiated area even further. These arrays can be costly $(>\$ 1,000)(19)$, or low in price $(<\$ 25$, the present study). Such advantages may render LEDs as a popular light modality in the 5-ALA-PDT of patients with CRC.

The present study found that violet light (399 nm) was highly effective. This is in agreement with the study by Gederaas et al (20), who found that while SW480 cells accumulated less PpIX than other cell lines, treatment with $1 \mathrm{~J} / \mathrm{cm}^{2}$ caused $\sim 50 \%$ cell death. Violet light has also been shown to be the most effective at creating reactive oxygen species, reducing cell viability and driving necrosis in a range of gastric cancer cell lines, albeit not with the selectivity demonstrated herein (21). The results of the present study, as shown in Fig. 5, demonstrated that in the presence of $1 \mathrm{mM} 5$-ALA, only $0.08 \mathrm{~J} / \mathrm{cm}^{2}$ was required to lead to a $50 \%$ reduction in viability. Differences in light sources could explain the differences in results; the LED in the present study emitted a narrow band of light, whereas the lamp used in the study by Gederaas et al (20) spanned 340-440 nm. These fluences were much lower than those published in the literature. Previous research using gastric cell lines only yielded results with $1 \mathrm{mM} 5$-ALA and $3 \mathrm{~J} / \mathrm{cm}^{2}$ light fluence, although almost $100 \%$ of the cells had died under these conditions (21). However, the wavelength used herein was also different from that in the majority of studies $(8,14,22-25)$.

In the present study, red, green and blue LEDs failed to produce significant cell death with fluences of $\sim 3.5 \mathrm{~J} / \mathrm{cm}^{2}$. Previously, other researchers used red light, albeit at fluences higher than used herein: Human gingival $\mathrm{Ca} 9-22$ cells treated with $1 \mathrm{mM} 5$-ALA required $4.3 \mathrm{~J} / \mathrm{cm}^{2}$ red light $(635 \mathrm{~nm})$ to achieve 50\% cell death (22); SW480 cells treated with 5-ALA 
(500 $\mu \mathrm{M}-1.5 \mathrm{mM}$ ) required $60 \mathrm{~J} / \mathrm{cm}^{2}$ red light to cause a reduction in viability (23); KLN205 lung cancer cells treated with $1.2 \mathrm{mM}$ 5 -ALA and $10 \mathrm{~J} / \mathrm{cm}^{2}$ red light $(630 \mathrm{~nm})$ reduced cell viability to $42 \%$; concentrations as high as $5 \mathrm{mM}$ did not cause further death (24). Blue light (405 $\mathrm{nm}$ ) has been reported to cause an 20-fold greater photobleaching of PpIX than red light $(635 \mathrm{~nm})$ following 5-ALA treatment; this has been associated with the ability of PDT to induce cell death (25). In the absorption spectrum of PpIX, compared with the 630-635 nm absorbance peak, the Soret peak (400-500 nm) is relatively 20-30-fold greater (8). While red light is used clinically with 5-ALA, the energy required to activate the $\mathrm{PpIX}$ does cause local heat damage (14).

The observations of the present study that violet light was a far superior light source for activating PpIX may offset the greater penetration of red light $(650 \mathrm{~nm}, 4-5 \mathrm{~mm})$ over violet light $(395 \mathrm{~nm}$, $<1 \mathrm{~mm}$ ) (26). In addition, the lower required fluence of violet light reduces pain and erythema when performing 5-ALA-PDT on skin (14). As previously demonstrated, HT-29 human CRC cells, both in vitro and subcutaneously inoculated in vivo, were more efficiently killed using blue light (456 nm) than using white (broad-band) or red (635 nm) light (8). By contrast, data modelling light travelling through blood and tissue has demonstrated that violet light $(405 \mathrm{~nm})$ is quenched more readily than red light (633 nm), and is less suitable for most diagnostic uses, despite the fluorescence signal of PpIX requiring a 50-100-fold higher fluence of red light than violet light (27). Despite this lack of penetration by violet-blue light, it has been successfully used in identifying tumour location during surgery (28).

As the present study demonstrated violet light as being the most therapeutic, the 5-ALA concentration-response association was examined under violet irradiation. The consequent analysis successfully demonstrated a 5-ALA concentration-dependent decrease in the viability of SW480 cells. Previous studies have demonstrated that the effects of 5-ALA can be reversed with Z-VAD(OMe)-FMK, indicating apoptosis in some conditions (29). Others have demonstrated that 5-ALA causes cell death through autophagy $(30,31)$, whereas some researchers claim that neither pathway is involved (32). The present study observed that the death of SW480 cells was partially reversed by 3-methyladenine, whereas Z-VAD(OMe)-FMK did not exert an effect. This suggests that autophagy, rather than apoptosis was the main route of cell death in the system used herein.

More importantly, the present study demonstrated that the type of multi-well plate used in these studies markedly affects the results obtained. It is common practice that black-walled multi-plates are used $(19,33)$. The present study demonstrated that this may restrict light exposure to all the cells in all the wells. The results identified that the maximal reduction was $\sim 75 \%$. It was suggested that some of the cells around the periphery of each well may be protected from light as the wall side may cast a shadow. By contrast, clear plates also introduce challenges: Merely covering wells with aluminium foil that are not planned for light exposure (16) is insufficient, as the cells in these wells do receive sufficient light exposure to cause PDT-mediated cell death. We advise the use of clear plates, with individual plates being used for each time point. While costly, this will lead to an improved quality of data.

In conclusion, the present study demonstrates that the use of LEDs in 5-ALA-PDT induces the death of SW480 CRC cells in vitro, with violet LEDs producing the optimal antitumour effect. The use of black-walled multi-plates may lead to disappointing results and may underestimate the effects of PDT in in vitro assays.

\section{Acknowledgements}

The authors would like to thank Ms. Fatima Al Hannan, RCSI-Bahrain, for providing technical support.

\section{Funding}

The present study was funded by RCSI-Bahrain Research Summer School.

\section{Availability of data and materials}

The datasets used and/or analysed during the current study are available from the corresponding author on reasonable request.

\section{Authors' contributions}

STS and FZH designed and supervised the study. ETS, HAOM, UJA, FA and STS performed the experiments and collected and analysed the data. ETS drafted the manuscript. ETS and STS confirm the authenticity of the raw data. All authors amended the manuscript and have read and approved the final version.

\section{Ethics approval and consent to participate}

Not applicable.

\section{Patient consent for publication}

Not applicable.

\section{Competing interests}

The authors declare that they have no competing interests.

\section{References}

1. World Health Organization (WHO): Cancer. WHO, Geneva, 2018. https://www.who.int/news-room/fact-sheets/detail/cancer. Accessed April 6, 2020.

2. Manfredi S, Bouvier AM, Lepage C, Hatem C, Dancourt V and Faivre J: Incidence and patterns of recurrence after resection for cure of colonic cancer in a well defined population. Br J Surg 93: 1115-1122, 2006.

3. Schmuck R, Gerken M, Teegen EM, Krebs I, KlinkhammerSchalke M, Aigner F, Pratschke J, Rau B and Benz S: Gender comparison of clinical, histopathological, therapeutic and outcome factors in 185,967 colon cancer patients. Langenbecks Arch Surg 405: 71-80, 2020.

4. Hofseth LJ, Hebert JR, Chanda A, Chen H, Love BL, Pena MM, Murphy EA, Sajish M, Sheth A, Buckhaults PJ and Berger FG: Early-onset colorectal cancer: Initial clues and current views. Nat Rev Gastroenterol Hepatol 17: 352-364, 2020.

5. Vogel JD, Eskicioglu C, Weiser MR, Feingold DL and Steele SR: The american society of colon and rectal surgeons clinical practice guidelines for the treatment of colon cancer. Dis Colon Rectum 60: 999-1017, 2017

6. Cox JD, Stetz J and Pajak TF: Toxicity criteria of the radiation therapy oncology group (RTOG) and the european organization for research and treatment of cancer (EORTC). Int J Radiat Oncol Biol Phys 31: 1341-1346, 1995. 
7. Van der Jeught K, Xu HC, Li YJ, Lu XB and Ji G: Drug resistance and new therapies in colorectal cancer. World J Gastroenterol 24: 3834-3848, 2018.

8. Hatakeyama T, Murayama Y, Komatsu S, Shiozaki A, Kuriu Y, Ikoma H, Nakanishi M, Ichikawa D, Fujiwara H, Okamoto K, et al: Efficacy of 5-aminolevulinic acid-mediated photodynamic therapy using light-emitting diodes in human colon cancer cells. Oncol Rep 29: 911-916, 2013.

9. Liu H, Daly L, Rudd G, Khan AP, Mallidi S, Liu Y, Cuckov F, Hasan T and Celli JP: Development and evaluation of a low-cost, portable, LED-based device for PDT treatment of early-stage oral cancer in resource-limited settings. Lasers Surg Med 51: 345-351, 2019.

10. Mroz P, Yaroslavsky A, Kharkwal GB and Hamblin MR: Cell death pathways in photodynamic therapy of cancer. Cancers (Basel) 3: 2516-2539, 2011

11. Peng Q, Warloe T, Berg K, Moan J, Kongshaug M, Giercksky KE and Nesland JM: 5-Aminolevulinic acid-based photodynamic therapy. Clinical research and future challenges. Cancer 79: 2282-2308, 1997.

12. Dougherty TJ, Gomer CJ, Henderson BW, Jori G, Kessel D, Korbelik M, Moan J and Peng Q: Photodynamic therapy. J Natl Cancer Inst 90: 889-905, 1998.

13. Ishizuka M, Abe F, Sano Y, Takahashi K, Inoue K, Nakajima M, Kohda T, Komatsu N, Ogura S and Tanaka T: Novel development of 5-aminolevurinic acid (ALA) in cancer diagnoses and therapy. Int Immunopharmacol 11: 358-365, 2011.

14. Mikolajewska P, Iani V, Juzeniene A and Moan J: Topical aminolaevulinic acid- and aminolaevulinic acid methyl ester-based photodynamic therapy with red and violet light: Influence of wavelength on pain and erythema. Br J Dermatol 161: 1173-1179, 2009.

15. Mansoury M, Hamed M, Karmustaji R, Al Hannan F and Safrany ST: The edge effect: A global problem. The trouble with culturing cells in 96-well plates. Biochem Biophys Rep 26: 100987, 2021.

16. Austin E and Jagdeo J: An in vitro approach to photodynamic therapy. J Vis Exp 138: e58190, 2018.

17. Cory AH, Owen TC, Barltrop JA and Cory JG: Use of an aqueous soluble tetrazolium/formazan assay for cell growth assays in culture. Cancer Commun 3: 207-212, 1991.

18. Tyrrell RM, Werfelli P and Moraes EC: Lethal action of ultraviolet and visible (blue-violet) radiations at defined wavelengths on human lymphoblastoid cells: Action spectra and interaction sites. Photochem Photobiol 39: 183-189, 1984.

19. Kercher EM, Zhang K, Waguespack M, Lang RT, Olmos A and Spring BQ: High-power light-emitting diode array design and assembly for practical photodynamic therapy research. J Biomed Opt 25: 1-13, 2020.

20. Gederaas OA, Schønberg SA, Ramstad S, Berg K, Johnsson A and Krokan HE: Cell specific effects of polyunsaturated fatty acids on 5-aminolevulinic acid based photosensitization. Photochem Photobiol Sci 4: 383-389, 2005.

21. Hino H, Murayama Y, Nakanishi M, Inoue K, Nakajima M and Otsuji E: 5-Aminolevulinic acid-mediated photodynamic therapy using light-emitting diodes of different wavelengths in a mouse model of peritoneally disseminated gastric cancer. J Surg Res 185: 119-126, 2013.
22. Tsai JC, Chiang CP, Chen HM, Huang SB, Wang CW, Lee MI, Hsu YC, Chen CT and Tsai T: Photodynamic therapy of oral dysplasia with topical 5-aminolevulinic acid and light-emitting diode array. Lasers Surg Med 34: 18-24, 2004.

23. Kawczyk-Krupka A, Sieron-Stoltny K, Latos W, Czuba ZP, Kwiatek B, Potempa M, Wasilewska K, Król W and Stanek A: ALA-induced photodynamic effect on vitality, apoptosis, and secretion of vascular endothelial growth factor (VEGF) by colon cancer cells in normoxic environment in vitro. Photodiagnosis Photodyn Ther 13: 308-315, 2016.

24. Osaki T, Yokoe I, Takahashi K, Inoue K, Ishizuka M, Tanaka T, Azuma K, Murahata Y, Tsuka T, Itoh N, et al: Metformin enhances the cytotoxicity of 5-aminolevulinic acid-mediated photodynamic therapy in vitro. Oncol Lett 14 1049-1053, 2017

25. Nadeau V, O'Dwyer M, Hamdan K, Tait I and Padgett M: In vivo measurement of 5-aminolaevulinic acid-induced protoporphyrin IX photobleaching: A comparison of red and blue light of various intensities. Photodermatol Photoimmunol Photomed 20: 170-174, 2004.

26. Ash C, Dubec M, Donne K and Bashford T: Effect of wavelength and beam width on penetration in light-tissue interaction using computational methods. Lasers Med Sci 32: 1909-1918, 2017.

27. Markwardt NA, Haj-Hosseini N, Hollnburger B, Stepp H, Zelenkov P and Rühm A: $405 \mathrm{~nm}$ versus $633 \mathrm{~nm}$ for protoporphyrin IX excitation in fluorescence-guided stereotactic biopsy of brain tumors. J Biophotonics 9: 901-912, 2016.

28. Corns R, Mukherjee S, Johansen A and Sivakumar G: 5-aminolevulinic acid guidance during awake craniotomy to maximise extent of safe resection of glioblastoma multiforme. BMJ Case Rep 2015: bcr2014208575, 2015.

29. Sugiyama Y, Hagiya Y, Nakajima M, Ishizuka M, Tanaka T and Ogura S: The heme precursor 5-aminolevulinic acid disrupts the Warburg effect in tumor cells and induces caspase-dependent apoptosis. Oncol Rep 31: 1282-1286, 2014.

30. Ji HT, Chien LT, Lin YH, Chien HF and Chen CT: 5-ALA mediated photodynamic therapy induces autophagic cell death via AMP-activated protein kinase. Mol Cancer 9: 91, 2010.

31. Liu T, Ma X, Ouyang T, Chen H, Xiao Y, Huang Y, Liu J and $\mathrm{Xu}$ M: Efficacy of 5-aminolevulinic acid-based photodynamic therapy against keloid compromised by downregulation of SIRT1-SIRT3-SOD2-mROS dependent autophagy pathway. Redox Biol 20: 195-203, 2019.

32. Lee MJ, Hung SH, Huang MC, Tsai T and Chen CT: Doxycycline potentiates antitumor effect of 5-aminolevulinic acid-mediated photodynamic therapy in malignant peripheral nerve sheath tumor cells. PLoS One 12: e0178493, 2017.

33. Schwake M, Nemes A, Dondrop J, Schroeteler J, Schipmann S, Senner V, Stummer W and Ewelt C: In-vitro use of 5-ALA for photodynamic therapy in pediatric brain tumors. Neurosurgery 83: 1328-1337, 2018.

This work is licensed under a Creative Commons Attribution 4.0 International (CC BY 4.0) License. 